\title{
On some agarics occurring in carr forests
}

\author{
ANNA BUJAKIEWICZ \\ Departament of Plant Ecology and Environment Protection, Adam Mickiewicz University \\ Umultowska 89, PL-61-614 Poznań, ascom@amu.edu.pl
}

Bujakiewicz A.: On some agarics occurring in carr forests. Acta Mycol. 45 (1): 73-89, 2010.

Remarks on ecology of several small agarics growing in carr forests of Querco-Ulmetum minoris and Astrantio-Fraxinetum type are presented and discussed. They all occupy special microhabitat (bare ground), belong to certain functional group (saprotrophs) and seem to be connected with carr forest habitat. The base rich or neutral soil humus, generally not favoured by fungi, together with extreme moisture and fast decomposition of litter causes that some humicolous macrofungi in carr forests form mostly small and short-living fruit bodies of hygrophyte character. They represent several genera: Conocybe, Coprinus, Cystolepiota, Entoloma, Flammulaster, Lepiota, Melanophyllum and Pholiotina of the order Agaricales. New localities are given, ecological amplitude is analised and preliminary mycosynusial consideration is presented.

Key words: mycocoenology, mycosynusial approach, agarics

\section{INTRODUCTION}

Carr forests belong to azonal vegetation, strictly connected with river valleys, streams and other water courses. They grow on rich, fertile, humose soil of black earth type and nourish lush, hygrophilous multilayer vegetation. Carr forests constitute in Poland only $0.086 \%\left(260.2 \mathrm{~km}^{2}\right)$ of the forested area (Matuszkiewicz 2001) and gradually and constantly diminish. If the ground water table decreases carr forests may turn into oak-hornbeam forests, in many areas however they are converted into arable lands, fields or pastures.

Riparian forests belong to threatened plant communities in Poland. Also in Wielkopolska region they requires special attention and protection. They preserve water sources and keep unique and still poorly known living world of plants, animals and fungi.

Almost all types of carr forests of the Alnion incanae Pawł. in Pawł. et al. 1928 alliance are protected in Wielkopolska region (Brzeg, Wojterska 2001) e.g., Carici 
remotae-Fraxinetum (E), Astrantio-Fraxinetum (V), Querco-Ulmetum minoris (V) and Fraxino-Alnetum (I).

The nature of substratum and moisture conditions play the most important role in the development and the distribution of fungi. Carr forests with their luxuriant vegetation, high humidity and rich soils are habitats distinguished by diversified and specific mycobiota, heterogenous in biological respect, comprising various saprotrophic and biotrophic fungi (Bujakiewicz 1989, 1992).

The goal of this paper is to turn the attention on the occurrence of several saprotrophic terrestrial agarics confined to naked humose soil observed in several studied phytocoenoses of the carr forests. Those fungi inhabit and exploit special microhabitat (rich humose soil) and express specific and variable composition of assemblages consisting emphemeral fructifications. They tend to occur simultaneously and repeatedly in similar habitat in many localities, manifesting some degree of dependence on carr forest habitat.

Macrofungocoenosis is regarded as intrinsic part of the plant community (Arnolds 1988, 1992). It comprises various groupings of fungi as regards to substratum, called mycosynusia. From three types of dependence of synusiae distinguished by Barkman (1973): ecological, topographical and syntaxonomic one, the latter is accepted in this paper.

\section{MATERIALS AND METHODS}

The material for analysis was gathered from 10 localities (Fig.1) and 15 observation plots taken from unpublished master theses (mscr.) and from authors unpublished data (Tab. 1). Master theses used in this publication were done within the period of 30 years, so degree of recognition of taxa, nomenclature and methods of study are very diversified.

Only 14 terrestrial saprotrophic species of macrofungi out of 90 taxa representing that niche-substrat group were selected and subjected to a comparative analysis in respect of relationship to carr forest habitat. They fulfill several significant requirements: occur in carr forests, form fructifications directly on naked humose ground, and their habitat preferences are confirmed in various ecological elaborations and monographs. The statement that species considered are saprotrophic and humicolous is based on the authors own observations and on literature accounts (e.g., Knudsen, Vesterholt 2008; Horak 2005) however it is obvious that in the field study a sharp line between soil and litter fungi is hard to detect and often not recognized.

Data originate from observations performed in phytocoenoses of the Querco-Ulmetum minoris and the Astrantio-Fraxinetum associations occurring in the Pojezierze Wielkopolsko-Kujawskie lakeland and in the Pojezierze Lubuskie lakeland. (Fig. 1). The soil in the carr forests was treated to be a homogenous substratum. Analyses of soil profile were not performed.

The observations are based on the occurrence of fruit-bodies. In Table 1 the temporal frequency is given and the abundance of fruit bodies acc. to Nespiak (1959) and Jahn et al. (1967). 


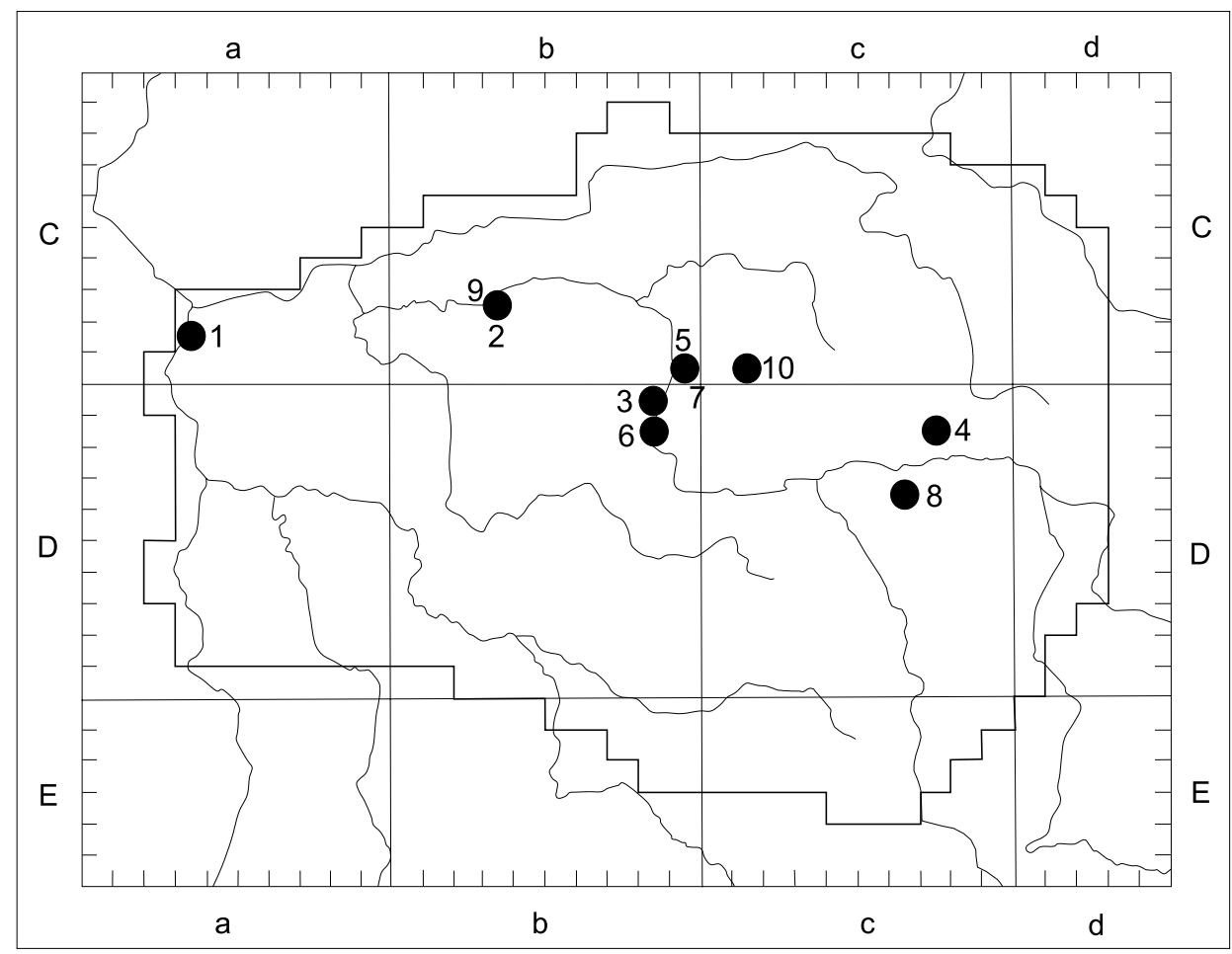

Fig. 1. Distribution of localities considered in the article (acc. to Żukowski et al. 2001). 1-Górzyca on the Odra river (Hojka 1978); 2-Sieraków (Nowak-Drózd 1978); 3 - Poznań, Dębina (Szwarc-Płoskoń 1983); 4 - Bieniszew (Gemzicka 1987); 5 - Annowo near Czerwonak (Borak 1992); 6 - Puszczykowo near Poznań (Susicka 1994); 7 - Radojewo near Poznań (Jaśkiewicz 1999); 8 - Kopojno (Bujakiewicz unpbl.); 9 - Sieraków Buki nad jez. Lutomskim (Springer 2008); 10 - Promno near Pobiedziska (Stefaniak 2008).

The nomenclature of the considered macrofungi is according to Knudsen and Vesterholt (2008) and Hausknecht (2009) and the geographical divisions of the area - after Kondracki (2001). Numerals of localities are given in bold types.

\section{RESULTS}

On the basis of gathered materials, short description of localities and ecological and chorological characteristic of selected macrofungi are given. Fungal species names are maintained original as in given theses but names of species selected to analysis are kept modern (Tab.1). In the lists of species within the localities (1-10) current names or synonyms of fungi considered in the present paper are given in bold types.

LOCALITY 1. (N52²9’35,3”; E14³9'17,9”) Górzyca on the Odra river, Pojezierze Lubuskie lakeland, Lubuski Przełom Odry, ca.10 km S of Kostrzyn, observation plot of $100 \mathrm{~m}^{2}$, Querco-Ulmetum minoris (sub. Fraxino-Ulmetum), 27 taxa of terrestrial saprotrophs: Agaricus arvensis $1^{+}$, Agaricus macrosporus $1^{4}$, Agaricus placomyces v. meleagris $3^{+-3}$, Agaricus silvicola $1^{+}$, Agrocybe praecox $1^{+}$, Clavulina cinerea $2^{3}$, Conocybe rickeniana $1^{+}$, Lepiota acutesquamosa $2^{+-1}$, Lepiota cristata $7^{1-2}$, Lepiota fulvella $1^{+}$, Lepiota hystrix $1^{1}$, 
A. Bujakiewicz

\begin{tabular}{|c|c|c|c|c|c|c|c|c|c|c|c|c|c|c|c|c|}
\hline & & DUE? & $\mathrm{SuO}_{-}^{-}$ & & & $\Xi$ & - & $-B$ & $\exists=$ & - & $\Xi$ & $\neg$ & $-1-$ & -1 & -1 & -1 \\
\hline 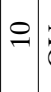 & ప & ل. & $-\approx$ & $\sum^{\infty}$ & $\stackrel{\infty}{\varrho}$ & $\stackrel{+}{-}$ & & & & & & \pm & & & & \\
\hline$a$ & 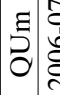 & 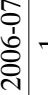 & $-\approx$ & 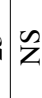 & $\stackrel{\infty}{\Xi}$ & & & & \pm & & & & & & & \pm \\
\hline$\infty$ & 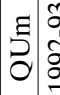 & 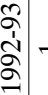 & $-m$ & 赵 & 軍 & $\stackrel{\text { D }}{2}$ & & $\stackrel{2}{2}$ & & $\stackrel{N}{\sim}$ & & & & & & \\
\hline$\wedge$ & $\begin{array}{c}1 \\
0 \\
0\end{array}$ & 年 & $\sqrt{N}$ & $\bar{\Sigma}$ & 8 & & & & & & & $\stackrel{ \pm}{\sim}$ & & & & \\
\hline 6 & 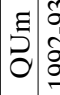 & 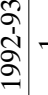 & & $\tilde{\Omega}$ & 8 & & & & & & & & & $\stackrel{+}{\sim}$ & & \\
\hline
\end{tabular}

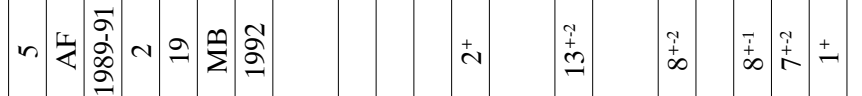

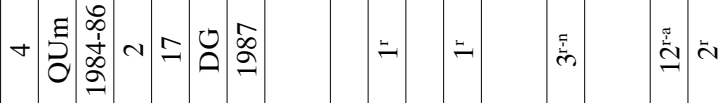

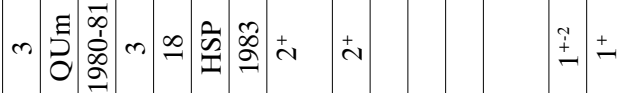

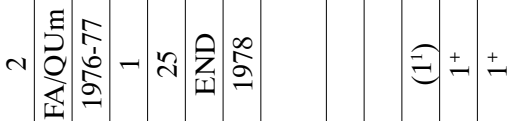

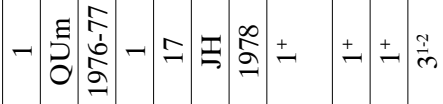

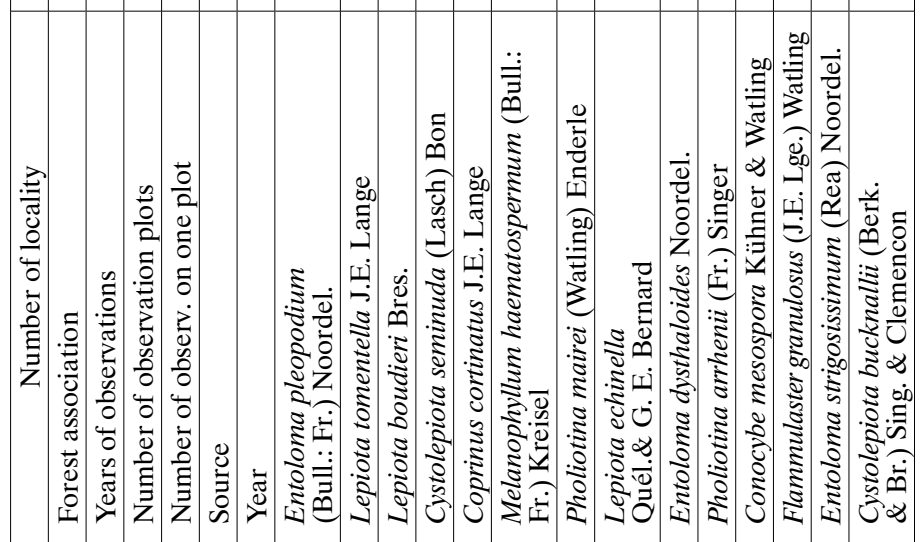


Lepiota naucina $1^{1}$, Lepiota seminuda f. minima $3^{+-1}$, Lepiota serena $1^{+}$, Lepiota tomentella $1^{+}$, Lycoperdon perlatum $2^{1}$, Macrolepiota rhacodes $2^{+-1}$, Melanoleuca schumacheri $2^{+}$, Phallus impudicus $2^{+-1}$, Psathyrella trepida $3^{1}$, Pustularia cupularis $5^{1-2}$, Rhodophyllus icterinus $1^{+}$, Rhodophyllus radiatus $2^{+-2}$, Sowerbyella radiculata $1^{2}$, Tubaria autochthona $1^{2}$, Tubaria pellucida $1^{1},\left[\right.$ Galera tenera f. tenella $\left.{ }^{1-3}\right]$ (Hojka 1978).

LOCALITY 2. (N52³8'56,8”; E1604'54,9”) Sieraków, Pojezierze Wielkopolsko-Kujawskie lakeland, Pojezierze Poznańskie lakeland, Buki Lutomskie Reserve on shore of Jezioro Lutomskie lake, observation plot of $200 \mathrm{~m}^{2}$, Fraxino-Alnetum/Querco-Ulmetum minoris (sub. Circaeo-Alnetum), 11 taxa of terrestrial saprotrophs: Coprinus cortinatus $1^{1}$, Lepiota cristata $1^{1}$, Lepiota fuscovinacea $1^{+}$, Lepiota seminuda f. minima $1^{1}$, Melanophyllum echinatum $1^{+}$, Psathyrella conopilea $1^{2}$, Psathyrella trepida $3^{+-1}$, Pustularia cupularis $5^{+-1}$, [Galera tenera $\mathrm{f}$. minor $1^{1}$, Galera tenera $\mathrm{f}$. microspora $2^{+-1}$, Galera tenera $\mathrm{f}$. tenella $1^{1}$ ] (NowakDrózd 1978).

LOCALITY 3. (N52²1’32,9”; E1654'57,7”) Poznań, Dębina, Pojezierze Wielkopolsko-Kujawskie lakeland, Poznański Przełom Warty gorge, Poznań-Wilda, Dębina forest, Querco-Ulmetum minoris (sub. Fraxino-Ulmetum), observation plots of 80-200 m², 19 taxa of terrestrial saprotrophs: Agrocybe praecox $1^{1}$, Calocybe gambosa $1^{+}$, Coltricia cinnamomea $5^{+-1}$, Conocybe pilosella $1^{1}$, Coprinus picaceus $1^{+}$, Entoloma icterinum $2^{+}$, Lepiota cristata $7^{+-2}$, Lepiota tomentella $2^{+}$, Lepiota setulosa $1^{+}$, Panaeolus rickenii $1^{1}$, Pholiotina aporos $2^{+}$, Pholiotina mairei $2^{+-2}$, Psathyrella conopilea $4^{+-2}$, Psathyrella spadiceo-grisea $1^{1}$, Psathyrella trepida $2^{1-2}$, Pustularia cupularis $1^{2}$, [Galera tenera $\mathrm{f}$. minor $4^{+-1}$, Galera tenera $\mathrm{f}$. microspora $1^{+}$, Galera tenera f. tenella $2^{+}$] (Szwarc-Płoskoń 1983).

LOCALITY 4. (N52¹7’12,65”; E18¹2’14,5”) Bieniszew, Pojezierze Wielkopolsko-Kujawskie lakeland, Pojezierze Kujawskie lakeland, ca 4 km SE of Kazimierz Biskupi, 8 km NW of Konin, two observation plots of $100 \mathrm{~m}^{2}$ each, Querco-Ulmetum minoris (sub. Ficario-Ulmetum campestris), 16 taxa of terrestrial saprotrophs: Calocybe gambosa $8^{\mathrm{n}-\mathrm{a}}$, Conocybe arrhenii $2^{\mathrm{r}}$, Conocybe brunneola $10^{\mathrm{r}}$, Conocybe filaris $1^{\mathrm{r}}$, Conocybe mairei $3^{\mathrm{r}-\mathrm{n}}$, Coprinus atramentarius $2^{\mathrm{r}}$, Coprinus cortinatus $1^{\mathrm{r}}$, Entoloma dysthaloides $12^{\mathrm{r}-\mathrm{a}}$ (sub. Entoloma babingtonii), Geastrum sessile $1^{\mathrm{r}}$, Lepiota fulvella $1^{\mathrm{r}}$, Lycoperdon perlatum $1^{\mathrm{r}}$, Mutinus caninus $3^{\mathrm{r}-\mathrm{n}}$, Mycenella bryophila $2^{\mathrm{r}}$, Phallus impudicus $1^{\mathrm{r}}$, Ramaria stricta $15^{\mathrm{n}-\mathrm{a}}$, Tubaria pellucida $1^{\mathrm{r}}$ (Gemzicka 1987).

LOCALITY 5. (N52³1'19,5”; E1656’19,3”) Annowo near Czerwonak, Pojezierze Wielkopolsko-Kujawskie lakeland, Pojezierze Gnieźnieńskie lakeland, Dziewicza Góra hill region, Astrantio-Fraxinetum, two observation plots of ca $200 \mathrm{~m}^{2}, 25$ taxa of terrestrial saprotrophs: Agaricus silvaticus $3^{+-2}$, Clitopilus cf scyphoides $2^{+}$, Conocybe abruptibulbosa $1^{+}$, Conocybe appendiculata $3^{+-1}$, Conocybe exannulata $3^{+}$, Conocybe mairei $13^{+-2}$, Conocybe magnicapitata $2^{+}$, Conocybe mesospora $8^{+-1}$, Conocybe plicatella $1^{+}$, Conocybe rickeniana $2^{2}$, Conocybe tenera $1^{+}$, Coprinus cortinatus $2^{+}$, Coprinus lagopus $4^{+-1}$, Entoloma byssisedum $1^{\mathrm{n}}$, Entoloma dysthaloides $8^{+-2}$, Flammulaster granulosus $7^{+-2}$, Lycoperdon perlatum $1^{+}$, Marcelleinia georgii $1^{2}$, Melanoleuca arcuata $1^{2}$, Mitrophora semilibera $1^{+}$, Morchella esculenta $1^{1}$, Mycenella bryophila $4^{+-1}$, Rhodophyllus lanicus $1^{+}$, Rhodophyllus strigosissimus $1^{+}$, Tubaria pellucida $2^{1-2}$, Volvariella murinella $4^{1-2}$ (Borak 1992).

LOCALITY 6. (N52¹7’09,6”; E1650’59,2”) Puszczykowo near Poznań, Pojezierze WielkopolskoKujawskie lakeland, Pojezierze Gnieźnieńskie lakeland, ca $20 \mathrm{~km} \mathrm{~S}$ of Poznań, Querco-Ulmetum minoris (sub. Fraxino-Ulmetum) one plot of $360 \mathrm{~m}^{2}, 7$ taxa of terrestrial saprotrophs: Agaricus bresadolianus $5^{+-3}$, Agaricus campestris $1^{+}$, Agaricus xanthodermus $2^{+}$, Conocybe mesospora $1^{+}$, Lepiota cristata $2^{+-1}$, Leucoagaricus leucothites $5^{1-2}$, Macrolepiota rhacodes $4^{1-3}$ (Susicka 1994).

LOCALITY 7. (N52²9'55,6”; E1656'51,4”) Radojewo near Poznań, Pojezierze WielkopolskoKujawskie lakeland, Pojezierze Gnieźnieńskie lakeland, Radojewo manorial park in northern part of Poznań, Querco-Ulmetum minoris with Viola odorata (sub. Violo odoratae-Ulmetum), two plots of 200 $\mathrm{m}^{2}$ each, 16 taxa of terrestrial saprotrophs: Agrocybe erebia $1^{+}$, Bovista pusilla $1^{+}$, Bovista nigrescens $7^{+-1}$, Conocybe plicatella $1^{+}$, Coprinus atramentarius $4^{+-2}$, Cystolepiota sistrata $2^{1-2}$, Entoloma dysthaloides $2^{+}$, Entoloma hirtipes $1^{+}$, Entoloma percandidum $1^{+}$, Entoloma sericeum $1^{+}$, Lepiota castanea $1^{+}$, Lepiota cristata $7^{+-1}$, Lycoperdon perlatum $2^{+-1}$, Macrolepiota mastoidea $1^{+}$, Macrolepiota procera $1^{\mathrm{n}}$, Mutinus caninus $3^{+-1}$ (Jaśkiewicz 1999). 
LOCALITY 8. (N5209’51,4”; E1759’26,3”) Kopojno, Pojezierze Wielkopolsko-Kujawskie lakeland, Pojezierze Kujawskie lakeland, ca $20 \mathrm{~km} \mathrm{SW}$ of Konin, one plot of ca $400 \mathrm{~m}^{2}$, Querco-Ulmetum minoris, 12 taxa of terrestrial saprotrophs: Agaricus xanthodermus $2^{2}$, Bovista nigrescens $1^{+}$, Calocybe carnea $2^{+}$, Coprinus ef lagopus $1^{+}$, Cystolepiota seminuda $2^{2-3}$, Entoloma icterinum $2^{3-5}$, Langermannia gigantea $2^{2}$, Lepiota cristata $1^{2}$, Lepista saeva $1^{2}$, Lepista sordida $1^{+}$, Macrolepiota rhacodes $2^{2}$, Melanophyllum echinatum $2^{1-2}$ (Bujakiewicz, unpubl.).

LOCALITY 9. (N52³7’36,5”; E1606’49,9”) Sieraków, Buki nad jez. Lutomskim reserve, Pojezierze Wielkopolsko-Kujawskie lakeland, Pojezierze Poznańskie lakeland, one observation plot of $200 \mathrm{~m}^{2}$, Querco-Ulmetum minoris, 3 taxa of terrestrial saprotrophs: Cystolepiota bucknallii $1^{+}$, Cystolepiota seminuda $2^{+}$, Lepiota castanea $1^{+}$(Springer 2008).

LOCALITY 10. (N52²7’03,5”; E17¹4’43,5”) Promno near Pobiedziska, Pojezierze Gnieźnieńskie lakeland, Querco-Ulmetum minoris, one plot of $300 \mathrm{~m}^{2}, 5$ taxa of terrestrial saprotrophs: Entoloma dysthaloides $1^{+}$, Entoloma pleopodium $1^{+}$, Lacrymaria lacrymabunda $1^{2}$, Lepiota cristata $1^{+}$, Tarzetta cupularis $2^{2}$ (Stefaniak 2008).

Macrofungi chosen for the discussion are rather rare however widespread. They grow in temperate deciduous forests especially in azonal carr forest of various types mostly in autumn and include members of the following families of the order Agaricales:

Agaricaceae: Coprinus cortinatus, Cystolepiota bucknallii, C. seminuda, Lepiota boudieri, L. echinella, L. tomentella, Melanophyllum haematospermum,

Bolbitiaceae: Conocybe mesospora, Pholiotina arrheni, Ph. mairei,

Tubariaceae: Flammulaster granulosus,

Entolomataceae: Entoloma dysthaloides, E. pleopodium, E. strigosissimum (Knudsen, Vesterholt 2008; Hausknecht A. 2009).

Macrofungi considered have perennial mycelium which penetrates the surface level of soil profile to the depth of several $\mathrm{cm}$. Their fruit bodies grow directly on bare, black humose ground, sometimes on conspicuously separated small lumps of earth or on caprolites. They were often observed growing close to rhizomes of Anemone spp. and bulbils of Ficaria verna. Only few of them are rarely and accidentally noted on dead plant remains. All are lignin decomposers.

Mostly due to delicate nature and small size of fruit bodies those species are not easily discernible and frequently overlooked.

It is clearly visible that selected macrofungi occur sparingly, rarely and scarcely and represent low degrees of frequency (Bujakiewicz 1989) (Tab. 1). The taxa are often not noticed during the visits because of short duration of sporocarps even if annual, temporal and spatial frequency of observations is high. Small and ephemeral fruit bodies of Coprinus cortinatus lasts only few hours, those of Pholiotina mairei one or two days and those of Melanophyllum haematospermum - several days. They all are confined to black humus (especially Lepiota echinella, L. tomentella, Melanophyllum haematospermum and Pholiotina mairei) some are confined to nitrogen in soil [(e.g., Entoloma pleopodium (Noordeloos 1992) and Conocybe arrheni (Ludwig 2007)] and others prefer calciphilous soil, e.g., Cystolepiota bucknalli, C. seminuda and Melanophyllum haematospermum (Herink 1989; Ludwig 2001). The last species is encountered even in greenhouses (Ludwig 2001).

All discussed 14 species of macrofungi are rare, e.g., Cystolepiota bucknallii, Entoloma strigosissimum, Flammulaster granulosus, Lepiota boudieri, L. echinella, L. tomentella and Pholiotina mairei or rather rare, e.g., Coprinus cortinatus, and Entoloma 
dysthaloides (Ludwig 2001, 2007; Kreisel 1978) and some are threatened e.g., Entoloma pleopodium, E. strigosissimum, Lepiota echinella, L. tomentella and Melanophyllum haematospermum (Wojewoda, Ławrynowicz 2006).

Data on the occurrence of some species on litter or even woody detritus, e.g., Entoloma strigosissimum, Flammulaster granulosus and Melanophyllum haematospermum (Ludwig 2001, 2007) may be connected with a specific habitat conditions in carr forests. Flooding usually covers plant remains (logs, branches, twigs etc.) with a thick deposits of silt and mud and smooth over substratum details. In that conditions it is often difficult or impossible to determine nutrient base.

\section{Coprinus cortinatus J. E. Lange}

Tiny ephemeral fruit-bodies of Coprinus cortinatus were noted always solitarily on black humus in phytocoenoses of the Fraxino-Alnetum/Querco-Ulmetum minoris associations, in September 1977 (2) ${ }^{1^{*}}$ (leg. E. Nowak-Drózd, det. A. Bujakiewicz), Querco-Ulmetum minoris in July 1984 (4) (leg. D. Gemzicka, det. A. Bujakiewicz), and Astrantio-Fraxinetum, in September and October 1989 (5) (leg. M. Borak, det. A. Bujakiewicz).

Coprinus cortinatus was noted in Poland in several localities, mainly in QuercoUlmetum minoris (Bujakiewicz 1964, 1973, 2001, Bujakiewicz, Kujawa 2000), but also in phytocoenoses of the Fraxino-Alnetum (Bujakiewicz 1973, Bujakiewicz et al. 1992) associations.

Terrestrial character of this species and connection with base rich soils is stressed by Watling (1982), Horak (2005) and Knudsen, Vesterholt (2008). Ludwig (2007) noted this rare species both on naked soil and on small woody debris.

Cystolepiota bucknallii (Berk. \& Br.) Sing. \& Clemenc.

Bright - coloured small fruit-bodies of this species were recorded in phytocoenosis of the Querco-Ulmetum minoris association on bare black humus, solitarily in October 2007 (9) (leg. N. Springer, det. A. Bujakiewicz).

Cystolepiota bucknallii is rare in Poland and up to now recorded in three localities only, i.e. in beech forest in calcareous mountains (Gumińska 1972) and in QuercoUlmetum minoris (Bujakiewicz 2001).

This Holarctic species is rather common in Western Europe, rare in Central Europe and is considered to be titly bound with calcareous soils (Kreisel 1987; Ludwig 2001). According to Darimont (1975) it is characteristic species of the fungal community ("sociomycie") Lepiotetum bucknallii wich occurs in phytocoenoses of the Acereto-Fraxinetum (Gradmann) Tüx. association in East Belgium montane forests.

Cystolepiota seminuda (Lasch) Bon [Lepiota seminuda f. minima (Lasch) Kummer, Cystolepiota sistrata (Fr.) Sing.]

Delicate, snow-white fruit bodies of Cystolepiota seminuda (Fig. 2) were recorded in phytocoenoses of the Querco-Ulmetum minoris association directly on black humose ground, numerously in July and November 1976, November 1977 (1) (leg. J. Hojka, det. A. Bujakiewicz), August and October 1997 (7) (leg. M. Jaśkiewicz, det. A. Bujakiewicz), September 1993, 1994 (8) (leg. det. A. Bujakiewicz), sparsely in September 2006 and July 2007 (9) (leg. N. Springer, det. A. Bujakiewicz). It was 
noted also in the Fraxino-Alnetum linking to Querco-Ulmetum minoris association, solitarily in July 1976 (2) (leg. E. Nowak-Drózd, det. A. Bujakiewicz).

This is an outstanding terrestrial saprobic species growing, almost excusively in deciduous forests and appearing almost always numerously or even abundantly. It is repeatedly noted from Poland mainly in the Querco-Ulmetum minoris (Friedrich 1994; Bujakiewicz 1997; Bujakiewicz et al. 2007; Kujawa 2008) growing in oak-hornbeam forests (Lawrynowicz 1973; Wojewoda 1974; Lisiewska, Rybak 1990; Bujakiewicz et al. 1997; Lisiewska, Połczyńska 1998; Bujakiewicz, Kujawa 2000), beech forests (Sałata 1972; Gumińska 1972; Friedrich 1994) and alder forests (Domański et al. 1963; Bujakiewicz 1993; Friedrich 1994).

Cystolepiota seminuda prefers neutral to base rich (Krieglsteiner 2003) or calcium rich soils (Kreisel 1987), and occurs sometimes on ruderal and other substitute places (gardens, parks etc.) rather on non fertilized soils (Ludwig 2001).

Lepiota boudieri Bres. (Lepiota fulvella Rea)

Delicate brown fructifications of Lepiota boudieri were recorded in phytocoenoses of the Querco-Ulmetum minoris association, solitarily in October 1976 (1) (leg. J. Hojka, det. A. Bujakiewicz) and in September 1986 (4) (leg. D. Gemzicka, det. A. Bujakiewicz).

Lepiota boudieri has only one published locality in Poland in the Pino-Quercetum association (Wojewoda 1974). It was recently recorded in phytocoenosis of the Carici remotae-Fraxinetum on fallen twig (leg. N. Springer, det. A. Bujakiewicz) (9) (Springer 2008).

This species is considered to be rare (Kreisel 1987), growing on rich and moist soils (Horak 2005; Knudsen, Vesterholt 2008) in most cases in deciduous forests, occasionally on calcium rich soil (Kreisel 1987).

Lepiota echinella Quél. \& G. E. Bernard (L. setulosa J. E. Lange)

Rough, grayish fruit bodies of L. echinella were collected in phytocoenoses of the Querco-Ulmetum minoris association, solitarily in August 1981 (3) (leg. H. SzwarcPłoskoń, det. A. Bujakiewicz).

Lepiota echinella was recorded several times in Poland equally in the QuercoUlmetum minoris (Lisiewska, Bujakiewicz 1976; Friedrich 1994, 2002; Bujakiewicz 1997; Kujawa 2008) and the Galio sylvatici-Carpinetum (Bujakiewicz, Fiklewicz 1964; Lisiewska 1965; Lisiewska, Bujakiewicz 1976). It was also noted in the Carici elongatae-Alnetum (Friedrich 1994, 2002) and the Dentario glandulosae-Fagetum (Sałata 1972). Separate locality derives from rich meadow Arrhenatheretum medioeuropaeum (Sadowska 1973). It has been recently found (October 27. 2009) in the Querco-Ulmetum minoris association in the Meteoryt Morasko reserve in Poznań (leg. B. Gnotońska, det. A. Bujakiewicz).

Lepiota echinella is considered to be rare and threatened in Europe (Kreisel 1987, Krieglsteiner 2003) and is endangered (E) in Poland (Wojewoda, Ławrynowicz 2006). It occurs in deciduous forests and thickets on fertile soils (Kreisel 1987; Enderle, Krieglsteiner 1989; Knudsen, Vesterholt 2008).

Lepiota tomentella J. E. Lange

This inconspicuous fungus was recorded in phytocoenoses of the Querco-Ulmetum minoris association, on naked ground, solitarily in October 1976 (1) (leg. J. Hojka, 


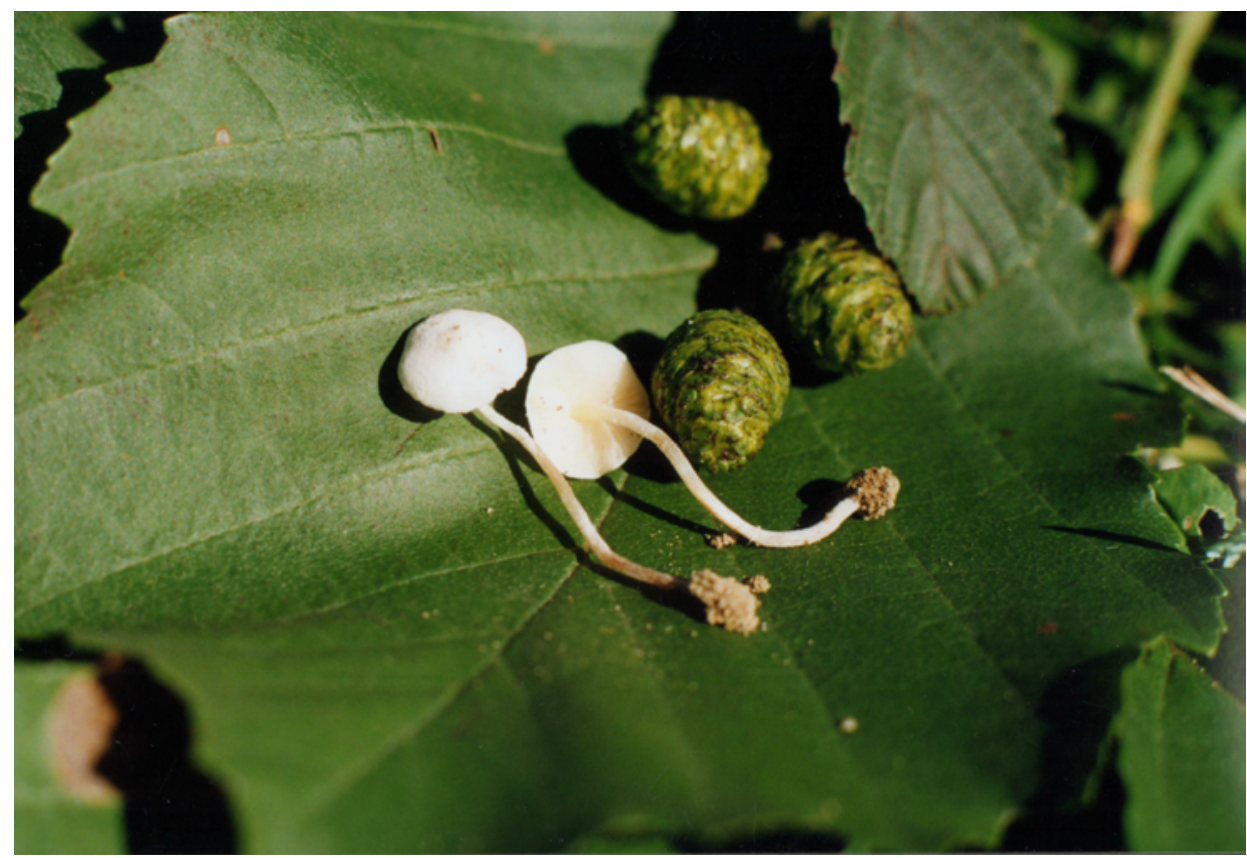

Fig. 2. Cystolepiota seminuda fairly common humicolous fungus growing in carr forests (Phot. A. Bujakiewicz).

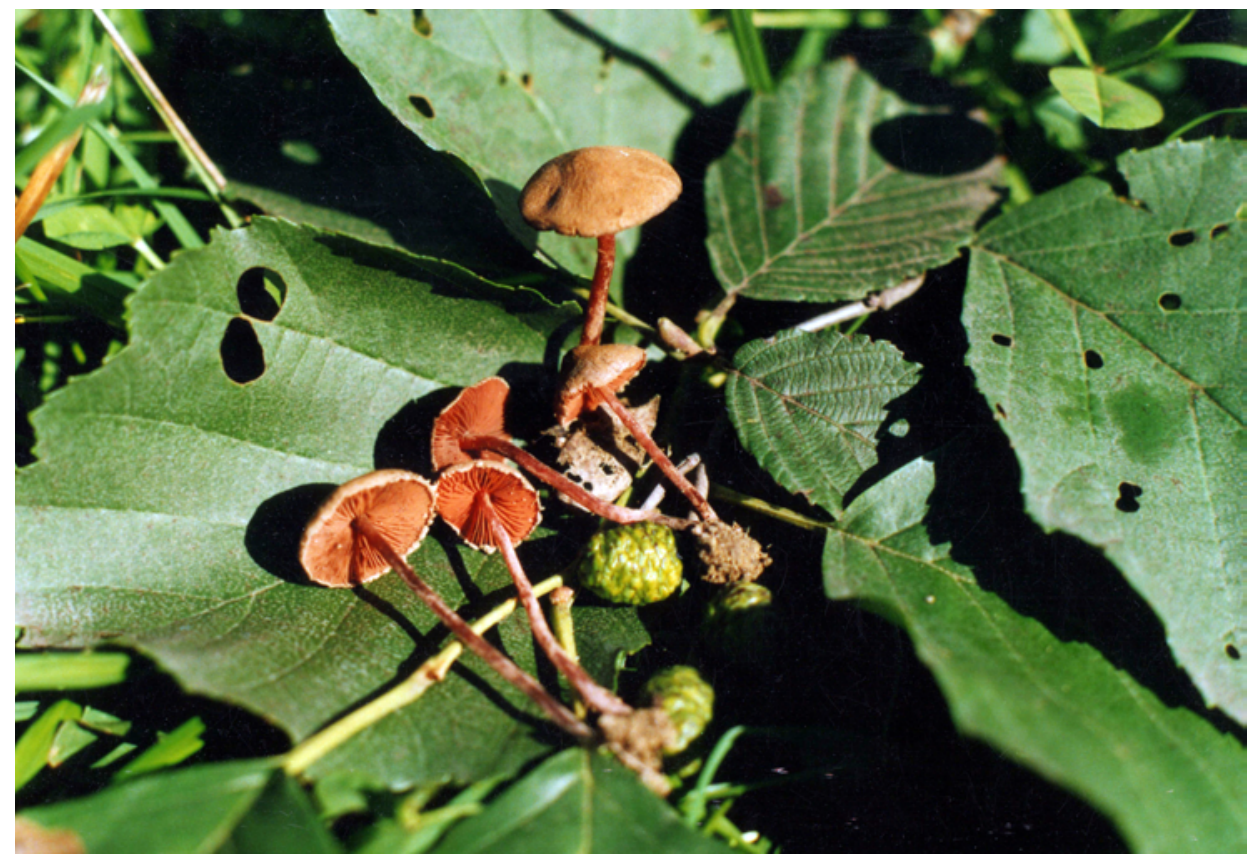

Fig. 3. Melanophyllum haematospermum growing on humus rich soils of the frondose forests (Phot. A. Bujakiewicz). 
det. A. Bujakiewicz) and in September 1980 (3) (leg. H. Szwarc-Płoskoń, det. A. Bujakiewicz).

It grows in various carr forests but also in oak-hornbeam forests (Bujakiewicz, Fiklewicz 1964, Lisiewska 1965), beech forests (Endler 1971; Sałata 1972) and was noted even in coniferous forests (Sałata 1972; Friedrich 1991, 2002).

Lepiota tomentella occurs in diverse alluvial and riparian forests, especially in Fraxino-Alnetum, in forests of the Rhine valley and is strongly threatened (Krieglsteiner 2003). It is also endangered (E) in Poland (Wojewoda, Ławrynowicz 2006).

Melanophyllum haematospermum (Bull.: Fr.) Kreisel [Melanophyllum echinatum (Roth: Fr.) Singer]

Colourful red brownish fruit bodies of this species (Fig. 3) were recorded in phytocoenoses of the Fraxino-Alnetum linking to Querco-Ulmetum minoris association, solitarily in September 1976 (2) (leg. E. Nowak-Drózd, det. A. Bujakiewicz) and in the patches of the Querco-Ulmetum minoris numerously in September 1993 and 1994 (8) (leg. det. A. Bujakiewicz).

Melanophyllum haematospermum has a dozen localities in Poland, derived mainly from rich deciduous forest of an oak-hornbeam type (Wojewoda 1966, 1974; Bujakiewicz et al. 1992, 1997, Lisiewska, Połczyńska 1998; Łuszczyński 2000), beech type (Domański et al. 1963) and carr forest type (Wojewoda 1974; Bujakiewicz 1993, 2006). It also occurred in phytocoenosis of the Petasitetum spp. (Gminder 1998), in fir forest (Gumińska 1972) and was noted in botanical gardens (Schröter 1889; Wojewoda 1996). Melanophyllum haematospermum is considered as rare (R) species in Poland (Wojewoda, Lawrynowicz 2006).

This species was formerly treated as rare but recently has expanded its distribution. It is connected with rich, fertile soils mainly of carr forests but grows also on compost piles and in ruderal places sometimes even in greenhouses (Ludwig 2001; Horak 2005; Knudsen, Vesterholt 2008). According to Kreisel (1987) it is probably nitrophilous and often synantropic. Its fruit bodies were found also on woody detritus (Ludwig 2001) or even on decaying wood (Kreisel 1987). Rimóczi (1994) stresses its occurrence in aspen-poplar woodlands where soil reaction is 8.1.

\section{Conocybe mesospora Kühner \& Watling}

Conocybe mesospora was recorded on naked ground, in phytocoenoses of the Astrantio-Fraxinetum association always solitarily in June 1989 and 1990, September 1990, 1991 and October 1991 (5) (leg. M. Borak, det. A. Bujakiewicz) and in phytocoenoses of the Querco-Ulmetum minoris association, solitarily in September 1992 (6) (leg. M. Susicka, det. A. Bujakiewicz).

Conocybe mesospora not common in Poland, has four published localities, in Querco-Ulmetum minoris (Bujakiewicz 1992, 1997; Nita, Bujakiewicz 2005) and along forest trail (Domański et al. 1967). It was recently recorded in the Carici remotaeFraxinetum association on woody debris buried in soil and in the Fraxino-Alnetum association on the ground (Springer 2008).

Its terrestrial habit is stressed by Watling (1982) and its incospicuosus occurrence by Ludwig (2008). According to Kreisel (1987) and Hausknecht (2009) it occurs more often on meadows, pastures, parks and in ruderal places than in deciduous forests. Similar valuation give Kreiglsteiner (2003), Horak (2005) and Knudsen \&Vesterholt (2008). 
Pholiotina arrhenii (Fr.) Singer [Conocybe arrhenii (Fr.) Kits van Wav.]

Small cream coloured specimens of Pholiotina arrhenii were noted in phytocoenoses of the Querco-Ulmetum minoris association, solitarily in October 1986 (4) (leg. D. Gemzicka, det. A. Bujakiewicz).

Pholiotina arrhenii seems to be rare in Poland. It was noted up to now in three localities, namely: in the Querco-Ulmetum association (Bujakiewicz 2001), in mixed Pino-Quercetum association (Wojewoda 1974) and in the botanical garden (Lisiewska, Mikołajczak 1998). It was recently recorded in manorial parks and oak woodlands (Kujawa 2008).

In Europe Pholiotina arrhenii appears to be widely distributed however not often recorded. Many authors stress its connection with rich humose soils (Watling 1982; Kreisel 1987; Breitenbach, Kränzlich 1995), some give remarks on the connections with lightly nitrophilous soils (Krigelsteiner 2003; Ludwig 2007) or with ruderal places (Horak 2005; Knudsen, Vesterholt 2008).

Pholiotina mairei (Watling) Enderle [Conocybe mairei Watl.]

Noted on bare humose ground in phytocoenoses of the Astrantio-Fraxinetum ass. where delicate fructifications occurred solitarily and scattered in June 1990 and fairly numerous in September and October 1989, 1990, 1991 (5) (leg. M. Borak, det. A. Bujakiewicz). Also recorded in the Querco-Ulmetum minoris association, sparsely in October 1984 and 1985 (4) (leg. D. Gemzicka, det. A. Bujakiewicz) and solitarily on plant debris in September 1981 (3) (leg. H. Szwarc-Płoskoń, det. A. Bujakiewicz).

Pholiotina mairei has several localities in Poland, all deriving from deciduous forests, mainly from carr forest, e.g., Querco-Ulmetum minoris (Bujakiewicz 1973; Friedrich 1994; Bujakiewicz, Kujawa 2000; Bujakiewicz 2001), Fraxino-Alnetum (Bujakiewicz 1973, Friedrich 1994) and parks established within great river valleys, e.g., Ciechocinek (Lisiewska, Wypij 1985). It was recorded also in the patched of the Carici elongatae-Alnetum association (Bujakiewicz 1973).

Pholiotina mairei is confined to Europe (Hausknecht 2009), shows very close association with carr forest habitats and is considered to be rare (Kreisel 1987; Horak 2005; Ludwig 2007; Knudsen, Vesterholt 2008) or very rare (Gminder, Krieglsteiner 2003) in some parts of Europe.

Flammulaster granulosus (J. E. Lange) Watling

Flammulaster granulosus was noted always on naked ground and numerously in phytocoenoses of the Astrantio-Fraxinetum association in August-November 1990 and solitarily in October 1991 (5) (leg. M. Borak, det. A. Bujakiewicz).

It is considered to be rare in Poland (Gumińska 1994) having only three published localities in Galio sylvatici-Carpinetum (Lisiewska-Połczyńska 1998), Dentario glandulosae-Fagetum (Gumińska 1994) and in orchard (Lisiewska, Balcerkiewicz 1991).

Flammulaster granulosus is not common in Europe (Vellinga 1986; Ludwig 2001). It shows wider nutrient base tolerance growing often among mosses and woody detritus (Kreisel 1987; Breitenbach, Kränzlin 1995; Horak 2005).

Entoloma dysthaloides Noordel.

Small, grayish, hairy fruit-bodies of this species easily fuse with the background and may be overlooked. Collected in four localities (Tab.1) on black humose ground 
in phytocoenoses of the Querco-Ulmetum minoris association, hidden among litter debris, abundantly in June 1984, 1985, 1986, sparsely in July 1984, 1985, August 1985, September 1986 and October 1985 (sub Entoloma babingtonii (Blox) Mos.) (4) (leg. D. Gemzicka, det. A. Bujakiewicz), rarely in October 1997 (7) (leg. M. Jaśkiewicz, det. A. Bujakiewicz), September 2007 (10) (leg. M. Stefaniak, det. A. Bujakiewicz), and in phytocoenoses of the Astrantio-Fraxinetum association sparsely in June 1990, July 1990, 1991, August and September 1990 (5) (leg. M. Borak, det. A. Bujakiewicz).

This taxon was only recently recognized in Poland and seems to be widespread but not common. It has only three localities up to now, namely in riverine forests with Alnus incana (Bujakiewicz 1993) and in the Querco-Ulmetum minoris association (Nita, Bujakiewicz 2005, 2007).

Horak (2005) recognized Entoloma dysthaloides as associated with carr forests, Noordeloos (1992) and Ludwig (2007) recorded it in wet places in deciduous forests often under Alnus and Fraxinus.

Entoloma pleopodium (Bull.: Fr.) Noordel. [Entoloma icterinum (Fr.: Fr.) M. M. Moser; Rhodophyllus icterinus (Fr.: Fr.) Quél.]

Fruit-bodies of Entoloma pleopodium were collected always on bare soil in phytocoenoses of the Querco-Ulmetum minoris, solitary in August 1977 (1) (leg. J. Hojka, det. A. Bujakiewicz) in August and September 1981 (3) (leg. H. Szwarc-Płoskoń, det. A. Bujakiewicz), in September 2006 (10) (leg. M. Stefaniak, det. A. Bujakiewicz), numerously in September 1993 and abundantly in September 1994 (8) (leg. det. A. Bujakiewicz).

Entoloma pleopodium is not common in Poland and is considered to be rare ( $\mathrm{R})$ (Wojewoda, Ławrynowicz 2006). It has seven published localities up to now, in it three are historical (Wojewoda 2003). It grows on the ground in forests with Alnus sp. Several localities are strictly connected with carr forests, e.g., Querco-Ulmetum minoris (Bujakiewicz 1973) and Fraxino-Alnetum (Bujakiewicz 1973; Bujakiewicz, Lisiewska 1983). It occurs terrestrially on humus-rich or nitrogen-rich soils under broad leaved trees (Ludwig 2007).

Strict connection of Entoloma pleopodium with carr forests and its terrestrial habit is confirmed by Krieglsteiner (2003). This species shows inclination to the occurrence in habitats rich in nitrogen, together with Urtica dioica, Aegopodium podagraria and Impatiens parviflora (Noordeloos 1992; Krieglsteiner 2003; Ludwig 2007). Rimóczi (1994) recorded it in Robinia - woodlands. It grows also in parks, gardens and pastures (Kreisel 1987).

Entoloma strigosissimum (Rea) Noordel. [Rhodophyllus strigosissimus (Rea) Noordel.]

Grayish, glistening hairy fruit-bodies of Entoloma strigosissimum were recorded in phytocoenoses of the Astrantio-Fraxinetum association, growing on fallen small twigs, solitary in July 1989 (5) (leg. M. Borak, det. A. Bujakiewicz).

Entoloma strigosissimum grows in deciduous forests on rich soil, among plant debris (Wojewoda 2003). It is rare and endangered (E) in Poland (Wojewoda, Lawrynowicz 2006) and has five published localities up to now: Querco-Ulmetum minoris (Bujakiewicz 1973, 1992), Carici remotae-Fraxinetum (Bujakiewicz 1969), 
Sorbo-Aceretum (Bujakiewicz 1979, 1981) and in montane beech forest (Gumińska 1981).

Entoloma strigosissimum is considered to be rare in Europe and seems to have a wider ecological amplitude. It has also wider nutrient base tolerance growing sometimes on decaying wood (Noordeloos 1992; Krieglsteiner 2003; Ludwig 2007; Knudsen, Vesterholt 2008). Horak (2005) defines is as terrestrial and lignicolous growing in carr forest and dry meadows.

\section{DISCUSSION AND CONCLUSIONS}

Mycocoenological studies, performed on permanent plots laid out in phytocoenoses of the strictly determined plant associations are the best method of studying the behaviour of fungi. The abundance of the fungi is determined by counting the fruit bodies. Observation plots visited through at least 3 years and performed two or three times per month in the growing season ensure to include the majority of components of mycocoenosis. During such intensive studies also specific fungal sporocarp nature, including short duration, periodicity and fluctuation in fruiting can be controlled to a certain degree.

Macrofungi have a great ecological, syntaxonomical and indicator value in all biocenoses. Due to narrow ecological susceptibility they are sensitive indicators of habitat conditions and can be differential species at least locally, of various phytocoenological syntaxa.

The development of fungus fruit bodies depends on ecological conditions of phytocoenosis as a whole. Fruit bodies are not randomly distributed but always according to some kind of interdependence (States 1981).

From the three main trophic (functional) groups, saprotrophic fungi are the most numerous. In carr forests lignicolous and litter saprothrophs predominate. Humicolous saprobionts are less numerous whereas perform unique species composition.

Humus may be considered an end product in the decomposition of lignin either from wood or herb layer. It is the amorphous dark brown or black organic material in the soil, distinct from partially decomposed plant and animal detritus. Humus is slowly decomposed by soil organisms, mostly fungi. Fungal habitat preferences are based on enzyme system adaptable to use by the fungus of specific fraction of the substratum such as cellulose, lignin, chitin and other compounds. Various species of fungi break down cellulose and hemicellulose but few only, comprising the considered taxa, are involved in lignin decomposition. Lignin is almost exclusively broken down by basidiomycete fungi, mostly macrofungi.

The base rich or neutral habitat of carr forests attracts the very specific and selected group of terrestrial fungi. Decomposition of litter in carr forests is very fast and the majority of this year litter being decayed in one year (Dziadowiec 1987).

Inspite of lush vegetation many phytocoenoses of carr forests especially of the Astrantio-Fraxinetum and Querco-Ulmetum minoris associations are distinguished by clearly visible surfaces of naked humose ground, free of herb layer. These places are often occupied by humicolous macrofungi. 
Sporocarps of those macrofungi are variable in appearance and periodicity. That is why they are not present in all stands considered and during all years of visits (Tab. 1). Usually only few species in mycocoenological observation plots is found to form fructifications each year within a period of three or more years. They are underrepresented in some phytocoenoses or even absent. It may be caused not only by short duration and periodicity of sporocarps. In some stands it is due to qualitative fluctuations when sporocarps of a species are completely absent during several years of study. Qualitative fluctuations are mostly caused by weather conditions but also ecological factors, like litter decomposition to humus form etc.

Ecological behavior and requirements of the 14 selected species of humicolous macrofungi incline to treat them as species more linked to habitat of certain phytocoenological syntaxa then litter saprotrophs and any other functional groups. They seem to form distinguishable element of a terminal stage of decomposition of lignin compounds in the humus. They form synusia-like grouping of humicolous saprotrophs, which may be provisionally called Pholiotina mairei - Entoloma pleopodium prov. grouping. Components of this fungal assemblage appear repeatedly or occur changeable in different localities (Tab. 1).

This humicolous synusium or some of its representatives seems to be differential for almost all types of the carr forests of the alliance Alnion incanae (previous AlnoPadion or Alno-Ulmion) inspite of the diverse trophic and moisture conditions. The uniformity of the microhabitat enables the uniformity of the fungal assemblage.

There are more humicolous species accompanying this synusial group, e.g., Mycenella bryophila (Gemzicka 1987; Borak 1992) which is rather rare in Poland (Komorowska 2005) and Lepiota castanea (Jaśkiewicz 1999; Springer 2008), Tubaria pellucida (Gemzicka 1987; Borak 1992) and Lepiota cristata (Hojka 1978; NowakDrózd 1978; Szwarc-Płoskoń 1983; Jaśkiewicz 1999; Bujakiewicz unpubl.; Stefaniak 2008) which are rather common and have wider ecological range. The same is true for nitrophilous species, e.g., Pholiotina filaris, which are accidentally found also in disturbed and ruderal places and frequently reported from greenhouses, e.g., Melanophyllum haematospermum.

Some components of the provisionally named Pholiotina mairei-Entoloma pleopodium assemblage were previously called out as supposed characteristic taxa in selected units of the carr forests, e.g., Entoloma pleopodium, E. strigosissimum for the Alnion incanae alliance and Cystolepiota bucknallii, C. seminuda and Melanophyllum haematospermum, for the Querco-Ulmetum minoris association (Bujakiewicz 1989). Further study confirmed the connection of Coprinus cortinatus, Entoloma strigosissimum, Melanophyllum haematospermum and Pholiotina mairei with the Alnion incanae alliance (Bujakiewicz 1992).

Several of the discussed 14 species of humicolous saprotrophs are rare in distribution some are endangered, e.g., Lepiota echinella (E), L. tomentella (E) and Entoloma strigosissimum (E) others are rare, namely Entoloma pleopodium (R) and Melanophyllum haematospermum (R).

It is reasonable to recall here Darimont's (1975) autonomous sociomycie of Lepiotetum bucknallii, described in phytocoenoses of the Acereto-Fraxinetum association in montane forests in East Belgium. Synusial similarities with an assemblage of saprotrophic humicolous macrofungi occurring in carr forests, remind this sociomycie. This community however is nitrophilous and hygrophilous and belongs 
to Inocybi-Lepiotion Darimont 1973 alliance of mycocoenoses of montane deciduous forests growing on calcium rich soils. Sociomycie of Lepiotetum bucknallii is very rich in species in all studied localities in Belgium. Striking is the common in both areas, occurrence of several mentioned accompanying macrofungi, e.g., Cystolepiota seminuda, Entoloma buckanallii, E. pleopodium Lepiota boudieri and Pholiotina filaris.

This is a preliminary article on the problem of mycosynusial assemblages of humicolous fungi in rich mull soil of carr forests. It requires further appropriate study and much longer observations.

\section{REFERENCES}

Arnolds E. 1988. Status and classification of fungal communities. (In:) J.J. Barkman, K.V. Sykora (eds). Dependent Plant Communities, 153-165. SPB Academic Publishing. The Hague.

Arnolds E. 1992. The analysis and classification of fungal communities with special reference to macrofungi. (In:) W. Winterhoff (ed.). Fungi in Vegetation Science. Handbook of vegetation science 19 (1) 7-47, Kluwer Academic Publishers.

Barkman J. J. 1973. Taxonomy of Cryptogam Communities (In:) V. H. Heywood (ed.). Taxonomy and Ecology, the Systematic Association. Special Volume 5: 141-180. London.

Borak M. 1992. Udział grzybów wyższych w płatach łęgu Astrantio-Fraxinetum i olsu Ribo nigri-Alnetum w rejonie Dziewiczej Góry pod Poznaniem. Praca magisterska wykonana w Zakładzie Ekologii Roślin i Ochrony Środowiska UAM w Poznaniu (mscr.).

Breitenbach J., Kränzlin F. 1995. Fungi of Switzerland. 4. Agaricaceae, Bolbitiaceae, Strophariaceae. Edition Mykologia Lucerne.

Brzeg A., Wojterska M. 2001. Zespoły roślinne Wielkopolski, ich stan poznania i zagrożenie. (In:) M. Wojterska (ed.). Szata roślinna Wielkopolski i Pojezierza Południowopomorskiego: 39-100. Przewodnik sesji terenowych 52 Zjazdu PTB, 24-28 września 2001. Bogucki Wyd. Nauk. Poznań.

Bujakiewicz A. 1981. Grzyby Babiej Góry. II. Wartość wskaźnikowa macromycetes w zespołach leśnych. a. Uwagi wstępne i charakterystyka lasów łęgowych regla dolnego. Acta Mycol. 17 (1/2): 63-125.

Bujakiewicz A. 1989. Macrofungi in the alder and alluvial forests in various parts of Europe and North America. Opera Botanica 100: 1-13.

Bujakiewicz A. 1992. Macrofungi on soil in deciduous forests. (In:) W. Winterhoff (ed.). Fungi in Vegetation Science 19 (1): 49-78, Kluwer Academic Publishers.

Bujakiewicz A. 1993. General remarks on macrofungi occurring in boreal and temperate grey alder forests. Blyttia 3/4: 99-110.

Bujakiewicz A. 1997. Agaricales. (In:) J. B. Faliński, W. Mułenko (eds). Cryptogamous plants in the forest communities of Białowieża National Park. Ecological atlas (Project CRYPTO 4). Phytocoenosis 9 (N.S.), Supl. Geographiae Geobotanicae 7: 304-407.

Bujakiewicz A. 1997. Macromycetes occurring in the Violo odoratae-Ulmetum campestris in the Bielinek Reserve on the Odra river. Acta Mycol. 32 (2): 189-206.

Bujakiewicz A. 2005. Again..."on the necessity of mycosociological studies in Poland". Acta Mycol. 40 (1): 7-14.

Bujakiewicz A. 2006. Macrofungi in the Caltho-Alnetum association on the northern slopes of the Babia Góra massif (West Carpathians). Polish Bot. Studies 22: 81-93.

Bujakiewicz A., Fiklewicz G. 1963. Grzyby wyższe lasów dębowo-grabowych okolic Opalenicy (pow. Nowy Tomyśl, Wielkopolska) Bad. Fizjogr. Pol. Zach., B 12: 277-300.

Bujakiewicz A., Chlebicki A., Chmiel M., Cieśliński S., Czyżewska K., Faliński J. B., Glanc Z., Głowacki Z., Klama H., Komorowska H., Lisiewska M., Majewski T., Mrozińska T., Mułenko W., Sadowska B., Skirgiełło A., Załuski T., Żarnowiec J. 1992. Check-list of cryptogamous and seminal plant species recorded during the period 1987-1991 on the permanent plot V-100. (In:) J. B Faliński, W. Mułenko (eds). Cryptogamous plants in the forest communities of Białowieża National Park. (Project CRYPTO) Phytocoenosis 3. (N.S.) Archivum Geobotanicum 4: 1-48.

Bujakiewicz A., Kujawa A. 2000. Macrofungi of manorial park in Turew near Poznań. Acta Mycol. 35 (2): 183-195. 
Bujakiewicz A., Lisiewska M., Nita J. 2007. Mikologia. Przewodnik do ćwiczeń terenowych i laboratoryjnych. Wyd. II. Uniwersytet im. A. Mickiewicza w Poznaniu, Wydz. Biologii. Biblioteka Pomocy Dydaktycznych Nr 2. Bogucki Wydawnictwo Naukowe.

Darimont F. 1975. Rechearches mycosociologiques dans les forests de Haute Belgique. Essai sur les frondements de la sociologie des champignons superieurs (2 tomes). Mém. Inst. Roy. Sci. Nat. Belg. 170.

Domański S., Gumińska B., Lisiewska M., Nespiak A., Skirgiełło A., Truszkowska W. 1963. Mikoflora Bieszczadów Zachodnich. II. (Ustrzyki Górne, 1960). Monogr. Bot. 15: 3-75.

Dziadowiec H. 1987. Decomposition of plant litter fall in oak-linden-hornbeam forest and an oak-pine forest of the Białowieża National Park. Acta Soc. Bot. Pol. 56 (1): 169-185.

Enderle M., Krieglsteiner G. J. 1989. Die Gattung Lepiota (Pers.) S.F. Gray emend. Pat. in der Bundesrepublik Deutschland (Mitteleuropa). Zeitschrift Mykologie 55 (1): 43-104.

Endler Z. 1971. Grzyby wyższe lasów bukowych nadl. Kąty. Acta Mycol. 7 (2): 279-298.

Friedrich S. 1991. Rzadkie i zagrożone grzyby wielkoowocnikowe w projektowanym Cedyńskim Parku Krajobrazowym. Zesz. Nauk. AR Szczecin, Rolnictwo 51: 107-119.

Friedrich S. 1994. Charakterystyka socjologiczno-ekologiczna mikoflory zbiorowisk leśnych Cedyńskiego Parku Krajobrazowego. Akademia Rolnicza w Szczecinie, Rozprawy 161: 1-100.

Friedrich S. 2002. Selected Ascomycota and Basidiomycota from Cedynia Landscape Park (NW Poland). Polish Bot. J. 47 (2): 125-138.

Gemzicka D. 1987. Udział grzybów wyższych w łęgu wiązowym w okolicach Bieniszewa (Nadleśnictwo Konin). Praca magisterska wykonana w Zakładzie Ekologii Roślin i Ochrony Środowiska UAM w Poznaniu (mscr.).

Gminder A. 1998. Eine Pilzgesellschaft bachbegleiten der Pestwurzbestände. Boletus 22 (2): 121-128.

Gminder A., Krieglsteiner G. J. 2003. Die Grosspilze Baden-Wüttembergs. 4. Ständerpilze: Blätterpilze II. Verlag Eugen Ulmer. Stuttgart.

Gumińska B. 1972. Mikoflora Pienińskiego Parku Narodowego. II. Acta Mycol. 8 (2): 149-174.

Gumińska B. 1994. Mikoflora Pienińskiego Parku Narodowego.VI. Fragm Flor. Geobot. Ser. Polonica 1: 33-39.

Hausknecht A. 2009. A monograph of the genera Conocybe Fayod, Pholiotina Fayod in Europe. Fungi Europaei Vol. 11. Edizioni Candusso.

Herink J. 1989. Rozšiřeni nekterŷch vybranŷch Boletales a Agaricales: Agaricus phaeolepidotus, Buchwaldoboletus lignicola, Cystolepiota bucknallii, Hygrophorus capreolarius a Russula viscida. (In:) F. Kotlaba, S. Šebek (eds). Aktuálni rozšiřèni některŷch druhů řas, mechů, lišejniků a hub v Československu: 24-29. Československa vědecka společnost pro mykologii při ČSAV. Praha.

Hojka J. 1978. Udział grzybów wyższych w płatach łęgu jesionowo-wiązowego w okolicach Górzycy nad Odrą. Praca magisterska wykonana w Zakładzie Ekologii Roślin i Ochrony Środowiska UAM w Poznaniu (mscr.).

Horak E. 2005. Röhrlinge und Blätterpilze in Europa. Elsevier. Spektrum Akademischer Verlag. Heidelberg.

Jahn H., Nespiak A., Tüxen R. 1967. Pilzsoziologische Untersuchungen in Buchenwäldern (Carici-Fagetum, Melico-Fagetum und Luzulo-Fagetum) des Wesergebirges. Mitt. Flor.-soziol. Arbeitsg. 11/12: 159-197.

Jaśkiewicz M. 1999. Grzyby wyższe (macromycetes) w fitocenozach zboczowego łęgu wiązowego Violo odoratae-Ulmetum campestris w podworskim parku w Radojewie koło Poznania. Praca magisterska wykonana w Zakładzie Ekologii Roślin i Ochrony Środowiska UAM w Poznaniu (mscr.).

Knudsen H., Vesterholt J. (eds). 2008. Funga Nordica. Agaricoid, boletoid and cyphelloid genera. Nordsvamp. Copenhagen.

Komorowska H. 2005. Mycenella bryophila (Vogl.) Singer (In:) W. Wojewoda (ed.). Atlas of geographical distribution of fungi in Poland 3: 65-68, W. Szafer Institute of Botany, Polish Academy of Sciences, Kraków.

Kondracki J. 2001. Geografia regionalna Polski. Wydawn. Naukowe PWN Warszawa.

Kreisel H. 1987. Pilzflora der Deutschen Demokratischen Republik. Basidiomycetes (Gallert-Hut-und Baupilze). VEB G. Fischer, Jena.

Kujawa A. 2008. Grzyby wielkoowocnikowe zadrzewień śródpolnych, parków wiejskich i lasów gospodarczych Parku Krajobrazowego im. Gen. Dezyderego Chłapowskiego, praca doktorska wykonana w Zakładzie Ekologii Roślin i Ochrony Środowiska, Uniwersytetu im. Adama Mickiewicza w Poznaniu (mscr.). 
Ławrynowicz M. 1973. Grzyby wyższe makroskopowe w grądach Polski Środkowej. Acta Mycol. 9 (2): 133-204.

Lisiewska M. 1965. Udział grzybów wyższych w grądach Wielkopolski. Acta Mycol. 1: 169-268.

Lisiewska M., Balcerkiewicz S. 1991. Macrofungi in orchards treated with herbicides. Boletus 15 (2): $45-56$.

Lisiewska M., Bujakiewicz A. 1976. V. Grzyby wyższe na tle zespołów leśnych. Roślinność rezerwatu „Dębina” pod Wągrowcem w Wielkopolsce. Bad. Fizjogr. Pol. Zach. B 44:7-50.

Lisiewska M., Mikołajczak M. 1998. Ogród Botaniczny Uniwersytetu im. A. Mickiewicza w Poznaniu jako środowisko przyrodnicze grzybów wielkoowocnikowych. Bad. Fizjogr. Pol. Zach. B 47: 7-44.

Lisiewska M., Połczyńska M. 1998. Changes in macromycetes of the oak-hornbeam forests in the „Dębina” reserve (Northern Wielkopolska). Acta Mycol. 32 (2): 191-230.

Lisiewska M., Rybak M. 1990. Udział macromycetes w zespołach leśnych parku w Uniejowie. Bad. Fizjogr. Pol. Zach. B 40: 5-28.

Lisiewska M., Wypij J. 1985. Mikoflora parków Ciechocinka. Bad. Fizjogr. Pol. Zach. B 36: 35-63.

Ludwig E. 2001. Pilzkompendium Bd. 1. IHW-Verlag. Eching.

Ludwig E. 2007. Pilzkompendium Bd. 2. FUNGICON - Verlag. Berlin.

Łuszczyński J. 2002. Preliminary red list of Basidiomycetes in the Góry Świętokrzyskie Mts (Poland). Polish Bot. Studies 47 (2): 183-193.

Matuszkiewicz J. M. 2001. Zespoły leśne Polski. Wydaw. Nauk. PWN, Warszawa.

Nita J., Bujakiewicz A. 2005. Grzyby wielkoowocnikowe w fitocenozach łęgu wiązowego Querco-Ulmetum minoris i olsu Carici elongatae-Alnetum w Lesie Złotowskim (Pomorze Zachodnie). Bad. Fizjogr. Pol. Zach. B, 54: 7-33.

Nita J., Bujakiewicz A. 2007. Łęgi i olsy ostoją rzadkich i zagrożonych grzybów wielkoowocnikowych. (In:) D. Anderwald (ed.). Siedliska i gatunki wskaźnikowe w lasach. 2. Studia i Materiały Centrum Edukacji Przyrodniczo-Leśnej 9 (2/3): 519-529, SGGW. Warszawa.

Noordeloos M. S. 1992. Entoloma ss. lato. Fungi Europaei. 5. Saronno.

Nowak-Drózd E. 1978. Udział grzybów wyższych w płatach łęgu olszowego Circaeo-Alnetum w rezerwacie „Buki Lutomskie” koło Sierakowa. Praca magisterska wykonana w Zakładzie Ekologii Roślin i Ochrony Środowiska UAM w Poznaniu (mscr.).

Rimóczi I. 1994. Die Grosspilze Ungarns. Zönologie und Ökologie, Libri Botanici 13:1-160.

Sadowska B. 1973. Preliminary evaluation of productivity of fungi (Agaricales and Gasteromycetes) on the Kazuń meadows. Acta Mycol. 9 (1): 91-100.

Sałata B. 1972. Badania nad udziałem grzybów wyższych w lasach bukowych i jodłowych na Roztoczu Środkowym. Acta Mycol. 8 (1): 69-139.

Schröter J. 1889. Die Pilze Schlesiens. Erste Hälfte. (In:) F. Cohn (ed.). Kryptogamen-Flora von Schlesien. 3. Band 1. Hälfte. J. K. Kern's Verlag, Breslau, 814 pp.

Springer N. 2008. Udział macromycetes w lasach łęgowych rezerwatu „Buki nad Jeziorem Lutomskim“ (Nadleśnictwo Sieraków). Praca magisterska wykonana w Zakładzie Ekologii Roślin i Ochrony Środowiska UAM w Poznaniu (mscr.).

States J. S. 1981. Useful criteria in the description of fungal communities. (In:) D. T. Wicklow (ed.). The fungal community, its organization and role in the ecosystem, 2: 185-199, Auburn Univ., Alabama.

Stefaniak M. 2008. Udział macromycetes w fitocenozach leśnych rezerwatu „Las liściasty w Promnie” (Nadleśnictwo Czerniejewo). Praca magisterska wykonana w Zakładzie Ekologii Roślin i Ochrony Środowiska UAM w Poznaniu (mscr.).

Susicka M. 1994. Udział grzybów (macromycetes) w fitocenozach łęgu Violo odoratae-Ulmetum (Weevers, 1940, Doing 1962) i łęgu wiązowego Ficario-Ulmetum campestris (Matuszkiewicz 1982), w rezerwacie Puszczykowskie Góry w Wielkopolskim Parku Narodowym. Praca magisterska wykonana w Zakładzie Ekologii Roślin i Ochrony Środowiska UAM w Poznaniu (mscr.).

Szwarc-Płoskoń H. 1983. Grzyby wyższe łęgu wiązowego (Ficario-Ulmetum) i grądu (Galio-Carpinetum) w Dębinie na terenie Poznania. Praca magisterska wykonana w Zakładzie Ekologii Roślin i Ochrony Środowiska UAM w Poznaniu (mscr.).

Vellinga E. C. 1986. The genus Flammulaster (Agaricales) in the Netherlans and adjacent regions. Persoonia 13 (1): 1-26.

Watling R. 1982. Bolbitiaceae: Agrocybe, Bolbitius \& Conocybe. (In:) D. Henderson, P.D. Orton, R. Watling (eds). British Fungus Flora: Agarics and Boleti. B. Royal Bot. Gdn., Edinburgh, 139 pp. 
Wojewoda W. 1966. Ojcowski National Park. (In:) A. Skirgiełło (ed.). Guide. Fourth Congress of European Mycologists, Poland: 71-79.

Wojewoda W. 1974. Macromycetes Ojcowskiego Parku Narodowego. Acta Mycol. 10 (2): 181-265.

Wojewoda W. 1996. Grzyby Krakowa w latach 1883-1994 ze szczególnym uwzględnieniem Macromycetes. Studia Ośr. Dokum. Fizjogr. Krakowski Oddz. PAN 24: 75-111.

Wojewoda W. 2003. Checklist of Polish larger Basidiomycetes. (In:) Z. Mirek (ed.). Biodiversity of Poland 7. W. Szafer Institute of Botany, Polish Academy of Sciences, Kraków, 812 pp.

Wojewoda W., Ławrynowicz M. 2006. Red list of the macrofungi in Poland. (In:) Z. Mirek, K. Zarzycki, W. Wojewoda, Z. Szeląg (eds). Red list of plants and fungi in Poland, W. Szafer Institute of Botany, Polish Academy of Sciences, Kraków: 53-70.

\section{O niektórych bedłkowcach występujących w lasach łęgowych}

\section{Streszczenie}

Artykuł zwraca uwagę na występowanie w fitocenozach lasów łęgowych szczególnej grupy grzybów saprotroficznych związanych z nagą żyzną próchniczą ziemią. Miejsca te zasiedlają gatunki, które zdają się tworzyć synuzjalne ugrupowanie grzybów prowizorycznie określone jako Pholiotina mairei - Entoloma pleopodium prov. W artykule podano nowe stanowiska 14 napróchnicznych gatunków grzybów saprotroficznych związanych z tym synuzjalnym ugrupowaniem, występujących w 10 miejscach na terenie Wielkopolski i Pojezierza Lubuskiego oraz zawarto dyskusję na temat ich skali synekologicznej. 